\title{
R\&D Cooperation and Firm Performance - Evaluation of Partnering Strategies in the Automotive Industry
}

\author{
David Elvers, Chie hoon Song* \\ Institute of Business Administration at the Department of Chemistry and Pharmacy, University of Muenster, Muenster, Germany \\ *Corresponding author: chiehoon.song@uni-muenster.de
}

Received June 16, 2014; Revised August 28, 2014; Accepted September 28, 2014

\begin{abstract}
The importance of $R \& D$ cooperation has been recognized as a consequence of growing complexity, dynamism of the environment, increasing risks and escalating costs of innovation. Collaboration with firms and academic institutions enables organizations to exploit external resources and competencies not available internally and adding additional value to the in-house ideas. Despite the large number of publications related to R\&D cooperation, empirical studies on the impact of firm's strategic partnering on firm performances are rather scarce. Thus, the goal of this paper is to contribute to the existing literature by discussing the strategic behavior of firms derived from the patent co-ownership network in order to establish a link between the variety of close relationships and the number of sold products. This paper discusses the influence of different strategic directions on firm performance, whereby the impact of uncertainty regarding the future technology development and the market acceptance is specifically high. First, the starting point is the analysis of co-patenting structure in the field automotive industry using patents related to lithium-ion batteries. This study investigates the characteristics of each resulting cluster derived from the collaboration network and then explores the heterogeneities of R\&D collaboration strategies differentiating between three types of strategic partnering: doing-it-alone, concentration on single partners and open partnering. Second, analysis is undertaken to establish an empirical linkage between the strategic partnering behavior and the number of sold electric vehicles. The results indicate that there is no direct causal link between the intensity of the cooperation and performance.
\end{abstract}

Keywords: R\&D cooperation, strategic behavior, patent co-ownership

Cite This Article: David Elvers, and Chie hoon Song, "R\&D Cooperation and Firm Performance Evaluation of Partnering Strategies in the Automotive Industry.” Journal of Finance and Economics, vol. 2, no. 5 (2014): 185-193. doi: 10.12691/jfe-2-5-9.

\section{Introduction}

Today's competitive business environment exposes the involved firms to various challenges. One of the key challenges of firms is the development and commercialization of new products and services in order to maintain or expand the market position (Schumpeter, 1934). To cope with the increasing complexity of business requirements, the following strategic options are commonly available means in the new product development (NPD): the launch of new products into existing markets, the launch of existing products into new markets and the launch of new products into new markets (Ansoff, 1965). This paper discusses the influence of different strategic directions on firm performance, whereby the impact of uncertainty regarding the future technology development and the market acceptance is specifically high. Technological uncertainty refers to the lack of knowledge, whether a technology will be favored in comparison with the established technology or other new emerging technologies in the targeted market segment (Jiang and Jain, 2012; Stoneman, 1983). Market uncertainty is defined as the uncertainty regarding the unknown development of markets. Hence, especially in the early stages of the development of a technology, satisfactory market size estimations can hardly be made (Meade and Islam, 2006).

It is a well-documented fact that $\mathrm{R} \& \mathrm{D}$ cooperation is a commonly applied strategy to reduce the cost of R\&D, to decentralize the risks and to stimulate the involved organizations to gain complementary resources. (Kliouch and Leker, 2011; Li and Calantone, 1998). The distinct and partially complementary capabilities of cooperation partner can contribute to increase the probability of success of the new technology and can lead to win-win scenario for all partners (Grant and Baden-Fuller, 2004; Hagedoorn and Narula, 1993; Hess and Rothaermel, 2011; Mowery et al., 1998). Hence, cooperation has become a crucial element of economic success in the knowledgeintensive business sectors. For example, due to Toyotas' success story, other market participants noticed that cooperation in buyer-supplier relationships can enhance the competitive position. Thus, the Toyota case was frequently analyzed during the end of the 80s and the 90s in the management and NPD literature. Outcomes of the studies indicated that the Japanese company could establish substantial advantages in lead time, cycling time and problem solving due to higher vertical integration and 
higher impact of trust and information transaction to their suppliers in comparison to their U.S. and European competitors. As a result, the shift from arm-length relationships to mutual relationships became more important in global management practice (e.g. Bensaou, 1997; Clark and Fujimoto, 1989; Cusumano and Takeishi 1993; Dyer and Ouchi 1993; Dyer 1997).

Another widely known example for successful cooperation is the development of Android (TM) under the leadership of google in the Open Headset Alliance (members: Google, HTC, LG, Sony, Samsung Electronics, Cetelix, etc.). The goal of Google and the consortium is to establish a software platform to set open standards for mobile devices such as smart phones and also to compete against the forward integrated market leader apple. In the beginning of 2014 Android TM is the market leader with a market share above 80 percent, which is not only favorable for Google, but for all players, because they got access to a dedicated software solution for their electronic articles.

This paper analyzes the impact of differing strategic partnering behavior of automobile manufacturers on their firm performances in the field of lithium-ion battery (LIB) technology for automotive applications. LIBs are regarded as a key enabling technology for the electro mobility (emobility). Electric vehicles or Plug-in Hybrids are vehicles, which use electric energy stored in the batteries as a power source. Due to their limited driving range caused by the low specific energy of the battery, it is still in its introductory phase with high growth potential. In addition, the purchase costs are still too high compared to vehicles with internal combustion engine, which negatively affect the buyer's purchase decision in current setting. They are dependent on the electric grid infrastructure, governmental support (tax benefits or subsidies) and heavily rely on the advancement in R\&D. Without resolving such uncertainties about industry wide compatibility, an increasing market acceptance by the end users is unlikely to occur (Kuester et al., 2000). Consequently, there always exists some degree of uncertainty about the future market development and technological capabilities in the beginning of the product life cycle (Meade and Islam, 2006). The aim of this study is therefore twofold: first, a cooperation network should be generated to detect the various partnering behavior of the involved industry actors at co-patenting level. Second, the impact of the strategic partnership on the outcome side should be examined by providing evidence of empirical link between the variety of close relationship sand the number of sold electric vehicles.

The remainder of the paper is organized as follows. In the next section, a brief review of literature on the importance of R\&D cooperation in today's competitive business environment is provided. In chapter three, the hypotheses are formulated. Subsequently, the measures associated with the process of research frame work and the empirical study are discussed, followed by an over view of the main results. Finally, some practical implications of this research are suggested and the chapter concludes with some limitations of this study. Possible future research directions are also provided.

\section{The importance of $R \& D$ cooperation}

Based on the assumption of heterogeneous allocation and immobility of resources, competitive advantages in the RBV are gained through firm specific resources, capabilities and competences (Barney, 1991; Teece et al., 1997; Wernerfelt, 1984). Resources include all tangible and intangible assets of a firm (Maijoorand van Witteloostuijn, 1996). Capabilities and competences are "complex bundles of skills and accumulated knowledge [...] that enable firms to coordinate and make use of their assets" (Day, 1994: 38). One of the key ideas of the RBV is the continuous development of firm specific resources and capabilities to create and keep competitive advantages in changing environments (Barney, 1991; Powell, 1992; Teece et al., 1997). Therefore, dynamic capabilities help firms to adapt to the changing market environment or to create market trends by integrating, reconfiguring, gaining and releasing resources (Eisenhardt and Martin, 2000: 1107).

In the recent past, internal resources and capabilities of firms are often not sufficient enough to generate new products and/ or services that meet the ever changing market requirements. Moreover, with blurring of boundaries between hitherto unrelated industry sectors, the required "knowledge set" can be found at both within and outside organizational boundaries (Bierly and Chakrabati, 2001; Chugan: 1995; Curran andLeker, 2011). In such cases, firms need to acquire the required resources and competencies externally. Firms have different options to get access to these resources: either by acquisition, merger or cooperation. Particularly in case where the markets are not well defined and established, R\&D cooperation is the most common solution (Hagedoorn and Narula, 1996). To integrate external partners into NPD, the internal integration capabilities such as organizational learning are a prerequisite (Droge et al., 2004; Flynn et al., 2010; Koufteros et al., 2005). If a company is seeking to pioneer a business, it should look for a strategic partner at an early stage of development to combine their competencies (Cao and Zhang, 2010; Das and Teng, 1998; Dyer and Singh, 1998; Flynn, 2002). Thus, from the firm's perspective, cooperation can be regarded as a necessity, when the NPD cannot be achieved in-house (or only with unacceptable risks), and as win-win situations for each involved party (Chesbrough, 2003; Eisenhardt and Schoonhoven, 1996; Parkhe, 1993).

There are several advantages of entering into a cooperation agreement during the R\&D phase. First, firms gain access to diverse key competences and capabilities, which could not be obtained from within company walls (Rothaermel, 2001, Hess and Rothaermel, 2011). Second, firms can build up ties and strengthen their relationship by developing products jointly. This is associated with a high flow of information and a building of mutual trust during collaborative work (Anderson and Narus, 1990). Third, the increasing level of trust and information flow can lead to a decrease in partnership uncertainty and thus to a better firm performance (Maloniand Benton, 2000). Finally, the complex market structure often creates a dependency between the buyer and raw material side. The better the level of trust and information exchange and the stronger the partnership in the cooperation are, less uncertainty will exist regarding the dependency on the partner (Cheung et al., 2010). Thus, R\&D cooperation can have positive direct effects on the innovativeness of a firm (market or 
technological input) and positive indirect effects (reduction of dependency, scouting, etc.).

Despite the fact that there are many positive opportunities created by collaborating within new product development, the risk factors do exist and should not be overlooked. On the one hand, the cooperating partner gets access to key expertise of the firm during the phase of the joint development, which might result in a loss of unique characteristics. On the other hand, a stronger supplier dependency can be established. Also investments can go wrong, because of misjudgments on choosing the right partners and collaborations (Song et al., 2013). But besides performance related risks, $R \& D$ cooperation can also entail relational risks. Apart from numerous objectives, the key objective of all firms is to generate sustainable revenues on a mid to long term basis. To this end, various firms pursue different strategies. Hence, the level of trust between the partners influences the effectiveness of coordination and thus can contribute to the success by reducing the transaction costs and organizational issues within the collaboration (Buckley and Carlson, 1988; Das and Teng, 1998; Handfield, 1993).

As a result, effective and efficient cooperation can just be achieved, if the general conditions are clarified from the beginning (Combs and Ketchen, 1999) and the orientation of each partner in approaching the collaboration is given (Das and Teng, 1998). Consequently, there are five main parameters to establish a successful cooperation: partner compatibility, investments from both sides, clear goals, management support, and establishment of a high level of trust, (Cao and Zhang, 2010; Whipple and Frankel, 2000; Devlin and Bleackley, 1988).

- Partner compatibility is defined as related mindset regarding the targets and the cooperation attitude increases the probability of success for the output of the cooperation (Das and Teng, 1998; Haeussler et al., 2010). Additionally, the choice of partnering should include complementary resources of the partnering firm. So in case of $R \& D$ cooperation, both sides should have the same level of innovativeness.. By segmenting the partners four dimensions for assessments are needed: base potential, growth potential, networking potential and learning potential. Base potential and growth potential build up the financial attractiveness of a potential collaboration partner. Networking potential deals with the up scaling potential of a project and learning potential is defined as the ability to get to know specific customer requirements and to create new products, which fit better to real market requirements (Gruner and Homburg, 2000, Vickery et al., 2011). Summarizing, shared values can act as a strong fundament for collaborations: Finding the right partner is crucial for positive performance outcomes.

- A mutual motivation to reach the goals of the cooperation must be given. Both the upstream partner (through the technological expertise) and the downstream partner (through adaptation of the technology) have to be interested in the solution (Rogers, 2003). Hence, investments from both sides are needed (Parkhe, 1993). Especially in case of R\&D cooperation, the partnership has a longer time horizon (Gatignon and Robertson, 1989).

- Before starting cooperation clear objectives and goals have to be set. Both parties have to agree in targets and the jointly developed NPD process. It is also advantageous, if there is a personal relationship of the involved parties, and key competences of all persons are known (Fliess and Becker, 2006).

- Senior Management support is encouraging the development of cooperation due to the character of mutual appreciation. Furthermore, the presence of senior management often leads to a higher level of development control. Thus, it supports the development of innovative, partner overlapping capabilities (Perks and Jeffery, 2006).

- Finally, there must be a dedicated level of trust between the partners. Once trust is established, generally communication frequency increases and transaction costs decreases (Morgan and Hunt, 1994).

\section{Hypothesis Development}

Electro mobility, the electrification of automotive transmissions leading to more environmentally benign and energy-efficient vehicles, is widely discussed in industry and academia since the climate debate has deeply penetrated into public and political consciousness. The market penetration rate of electric vehicles is still low; however, the related technological developments are experiencing a rapid growth. Thus, the research field LIB can be considered as an emerging field, since it plays a crucial role in improving energy supply and storage (Brown et al., 2010; Yang et al., 2013; Wagner et al., 2013). Based on these considerations, one may expect that in emerging technological areas the affected firms actively take part in research and development activities to promote its progress. Consequently, the following hypothesis is formulated:

H1: In an emerging field, typically the co-patenting activity of involved firms is high.

As firms differ in their core competencies and in strategic research focuses, they differ in their strategic partnering behavior. Hence, some firms tend to have a greater share of collaborative technological activities and others tend to collaborate less. Main goal of this paper is to identify those key strategic partnering behaviors. With regard to those, there are several models of collaboration available when engaging in joint research activities. But this paper narrows it down to following three main strategic approaches.

The first approach is called open strategic partnering. Open strategic partnering is defined as pursuing parallel $\mathrm{R} \& \mathrm{D}$ cooperation activities with multiple partners for the same R\&D topic. It is an open strategy, since the choice of cooperation partners is not restricted. In some cases, outcomes of the $R \& D$ activities are to some extent unpredictable, not only regarding the performance of the R\&D activities, but also because of the technology breakthrough. So spreading several opportunities for R\&D over multiple collaborations can reduce uncertainty in total. This can be part of a portfolio approach as it exists for several R\&D options of firms (Faems et al., 2005).

The second approach has been labeled as concentration on single partners. By following this approach, firms try to identify preferred partners before starting their joint R\&D activities. Thus, firms act on selected topics with single partners. Due to the commitment to the partner, the trust is likely to be on a higher level than at the open strategic partnering. Hence, stronger relationship to the 
R\&D partners can be built up by concentrating on single partners. (Dyer and Chu, 2003; Parkhe, 1993).

And finally, the third approach is the so-called doing-italone approach. By neglecting R\&D cooperation, firms achieve the R\&D activities single-handedly, whereby the transaction costs can be kept at a low level.
This approach is only feasible for firms, which are backwards integrated and have skills in more than one value creation processes (Chesbrough, 2003; Gemünden et al., 1996). Summarized, hypothesis 2 has been concluded:

H2: Firms differ in strategic partnerships. The resulting difference in strategic behavior can be clustered in to three main groups.

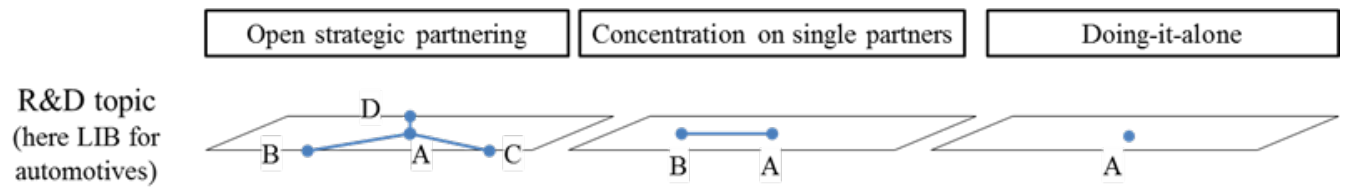

Figure 1. Main R\&D partnering approaches.(Source: Own figure)

There is a general consensus in the literature that cooperation helps to boost firm's innovation performance (Hagedoorn, 2002, Becker and Dietz, 2004, Veugelers and Cassiman, 2005). By integrating the relevant actors into cooperative and interdisciplinary research activities, a wider range of external knowledge can be obtained (Hagedoorn, 1993). However, the correlation between the varying level of cooperation and performance is not quite as simple as they seem. There is not always a linear relationship between the number of cooperation partners and corporate success. Especially in an emerging industry, it is often difficult to achieve 'first mover advantages' without having to cooperate with an external partner. On the contrary, too many partners may increase the organizational complexity and hence slow down the pace of the development progress. Therefore, it was assumed that firms concentrating on selective partner relationship are more successful than others. Following hypothesis is formulated:

H3: An inverted U-shape relationship exists between the degree of cooperation intensity and the firm performance.

\section{Empirical Study}

\subsection{Research Framework}

The research framework is designed to be performed in three consecutive phases, as shown in Figure 2. The following summarizes the rationale behind the thought process why this study decided to choose this particular approach and how the cooperation intensities are measured. The research framework mainly relies on the co-patenting behavior of technology-intensive industries. Patent information has been used for the purpose of examining the cooperative relations, since joint patent applications imply a particularly close relationship between two cooperating entities, because knowledge and expertise are shared equally by both parties before and after it is fully developed. Joint ownership of patents or other industrial property rights is not a common, but neither is a rare phenomenon. There is a rather growing trend towards increasing number of co-owned patents, despite of the fact that there are studies emphasizing its negative influence on the financial performance of the firm (Belderbos et al., 2010). According to Hagedoorn, co-patents are suboptimal and a second-best option that firms ought to avoid (Hagedoorn, 2003).

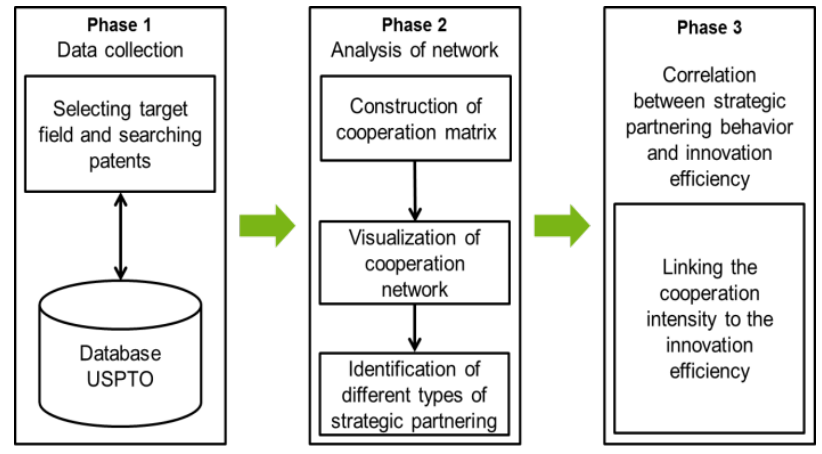

Figure 2. Overall process of the research framework. (Source: Own figure)

By considering the patent co-ownership to construct the cooperative relations, the following assumptions have been made: Patent co-ownership shows a high degree of commitment for the collaborative work from both parties involved and mutual trust, thus indicating that the proportion of shared knowledge is notably high (Belderbos et al., 2013; Hagedoorn et al., 2003). Companies usually form strategic alliances or build up a network with academic institutions and other companies for collaborative innovation. Companies seeking for joint research activities need to define beforehand the resulting status of the ownership of the invention. Licensing might be another option to share one's patent rights. However, when they decide to jointly apply for a patent, it can be interpreted as a willingness to cooperate in the further stage of the development of the invented technology. In this sense, a co-patent represents an output of a highly intensive business relationship.

In fact, mapping out the cooperative relation based solely on the patent information could be misleading and does not provide proper representation of the actual cooperation structures, because cooperation does not necessarily results in a patent application and the copatents thus only reflect a fraction of the firm's collaborative environment. Nevertheless, this patent-based cooperation network approach will give a different insight into the interrelation between the cooperation intensity and the innovation efficiency.

After obtaining the patent-based collaboration network, the key players of the automotive industries have been taken into consideration for further analysis. Network analysis method has been applied to measure the intensity of the cooperation and therefore to conclude the differing strategic behavior among the automobile manufacturers. 
The varying levels of cooperation intensity can be translated into an indicator for explaining their impact on the firm's performance. The innovation efficiency is measured at the corporate level in terms of the number of sold electric or hybrid vehicles (or sales figures), since it is an easily accessible, quantifiable and comprehensive source of information.

\subsection{Data: Using Patent Information (Patent Co-Ownership) To Map Out Inter-Firm Cooperation Networks}

Patent data related to the LIB technology, including the information on the applicants, are retrieved from the USPTO. Since LIBs are considered to be an integral part of the commercialization of electric vehicles, the research concentrates on the co-patenting behavior of automobile manufacturers in the field of battery research. Patents that are co-owned with individuals were eliminated from the data set. Also duplicates (co-existence of granted patent and patent application) were removed to avoid the double counting of the identical invention.

A total of 3377 patents have been gathered from which 189 patents in the time period between 2000 and 2013 are jointly owned by inter-firm cooperation or industryacademia partnerships. The majority of patents are classified as solitary invention activities. Collaborative researches are identified involving mostly two, but in some cases up to four partners simultaneously. Unsurprisingly, only a very small proportion of patents were filed by the automobile manufacturers.

\subsection{Measuring the Cooperation Intensity}

First, the starting point of the analysis is the modeling of the co-patenting network. The network has been developed by merely counting the number of jointly applied patents between at least two parties. Then, social network analysis technique has been applied to map the interrelations and to measure the intensity of resulting cooperation clusters. The assignees or applicants of the patent are represented by nodes in the network and the links serve as the relationships or "flows of interaction" between the nodes (Haythornthwaite, 1996). The thickness of the links, for example, symbolizes "the amount of resources exchanged”. (Two companies repeatedly engaging in joint ownership of patents are listed multiple times: The thicker the link, the more joint ownership of patents between two exists.)

To classify the characteristics of resulting cluster derived from the network, the degree centrality has been measured. Degree centrality is a concept applied to determine the relative importance or influence of a node in a network and measures the proportion of nodes that are adjacent to each node (Freeman, 1979). By transferring it to the conceptual approach of this study, it measures the extent to which a set of nodes (cooperating companies) are organized around the central node. (reference company) Using the concept of degree - the number of direct connections a single node can have - the degree centrality of a company in the network is defined as:

$$
\text { Degree centrality }=\frac{\sum_{i=1}^{n} \operatorname{link}_{i j}}{\# \text { nodes }-1}
$$

Link $_{i j}$ indicates the connectedness between the cooperating entity $\mathrm{i}$ and $\mathrm{j}$. This study adopts the degree centrality to quantify the cooperation intensities among the members of the network

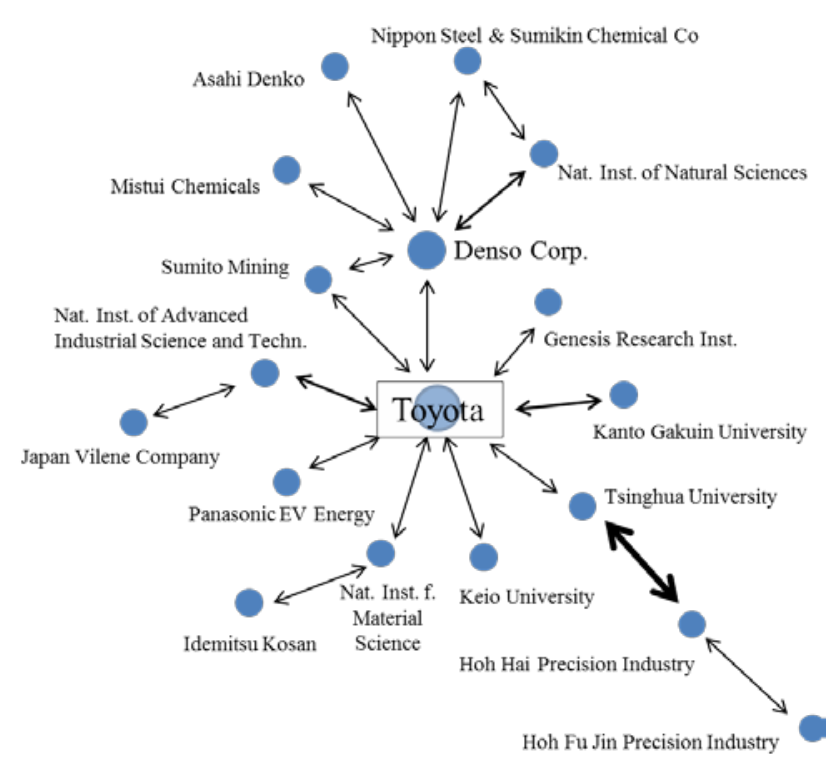

Figure 3. Example of a patent co-ownership network. (Source: Own figure)

\subsection{Innovation Efficiency}

To establish an empirical link between the variety of strategic partnering behavior and the innovation efficiency, an adequate comparative dimension needs to be selected as a dependent variable to describe and to measure the impact of the relationship. The dependent variable is the annual performance of a firm, measured by the number of sales figures. The data on the number of sold hybrid or electric vehicles have been mainly obtained from the annual reports and general press releases and through literature review.

Since the investment on the technological advancement, which, in most cases, might result in patent applications, generally become visible several years after the corresponding activities have been carried out, common indicators for measuring the performances of a firm, such as market and book value of firms or profit indicators (return on assets), did not seem reasonable. The sales figures have been applied as an abstract figure to compare the correlation between the degree of collaborative effort and its outcome.

\section{Results and Discussion}

The analysis revealed distinct patterns of strategic partnering behavior, whereby a considerable part of the automobile manufacturers (AMs) tend to avoid collaborative R\&D activities, at least not based on the patent level analysis. In fact, about 50 percent of the analyzed AMs barely show any significant patenting activities for the development of LIBs. Even though the overall patenting activity in the field of LIB research was constantly increasing over the last few years, AMs have significantly low amount of patented technologies in this area compared to the overall development. This indicates 
that they primarily rely on the actors from chemical and battery industries for the supply of the LIB. It further implies that the LIB powered electric vehicle market is still an infant market and thus there are still ongoing "hidden" research activities that might become more visible in the upcoming years, because of the existing time lag between the patent application and its publication. According to the findings of this research, about 10 percent of patents applied by AMs are co-owned. The average value of the co-owned patents among independent organizations varies in different studies. However its value is significantly lower in comparison to the findings from of the analysis. Giuri et al. (2007: 1115) and Hagedorrn (2003: 1041) found out that on average about $6,1 \%$ and $1,3 \%$ of the inventions were jointly owned by more than one organization. Thus, in agreement with the proposed hypothesis, the co-patenting activity of involved firms can be considered high. The high degree of co-owned patents by AMs can be traced back to the fact that there still exists a large knowledge gap between the actors from the traditional automotive industries and the suppliers concerning the development of advanced battery technologies and the AMs try to bridge this gap by building up a long-term relationship based on trust and experience, since it has been assumed that a co-patent represents an output of a highly intensive business relationship. In addition to that, a supplier might not have the incentive to engage in co-development, when the cooperating partner cannot provide the complementary capabilities. Thus, it can be concluded that the copatenting would benefit both parties to improve their performances.

In accordance with the second hypothesis, three common types of strategic partnering behavior could be recognized from studying the collected data set: Doing-italone, Concentrated and Open. The doing-it-alone approach refers to firms not seeking to share the equal rights to intellectual property and thus patenting alone. As a consequence, they do not own any join patents in the field of battery research. Concentrated relationship refers to firm that enters into a selective partnership. It implies that a firm only has limited organizational ties to other firms. Open relationship refers to firm with a wide range of partners. Through the use of active inflows and outflows of knowledge, firms tend to open up its boundaries to speed up the internal innovation.

To classify the automobile firms into the three categories, the degree centrality has been measured. The mean value of the network analysis is 1.1 Firms that belong to Doing-it-alone cluster do not have any centrality value, since they do not hold any joint patents. Firms with degree centrality greater than the mean value are considered to have an open strategic behavior. If the value is lower than the mean value, then it has been classified as concentrated. It has been shown that the majority of firms have adopted the doing-it-alone or concentrated partnership approach. The next table presents the clustering of key automobile manufacturers into their respective category strategic partnering behavior.

Only two companies are identified under the cluster of open strategic behavior. Toyota seems to have by far the largest number of co-owned patents. The analyses further show mixed trends in strategic partnering behavior. While Asian manufacturers such as Toyota, Hyundai and BYD prefer to establish a stronger tie to suppliers (or competitors) by joint ownership of patents, the western AMs such as Tesla Motors, BMW and Benz tend to not share its rights. This could be related to the cultural or organizational background.

Table 1. Different types of strategic behavior. (Source: Own figure)

\begin{tabular}{|c|c|c|}
\hline $\begin{array}{l}\text { Type of strategic } \\
\text { behavior }\end{array}$ & Key players & Degree centrality $\left(\right.$ in $\left.10^{-3}\right)$ \\
\hline \multirow{7}{*}{ Doing-it-alone } & Tesla Motors & - \\
\hline & Mercedes-Benz & - \\
\hline & BMW & - \\
\hline & Renault & - \\
\hline & Mitsubishi Motors & - \\
\hline & Volvo & - \\
\hline & Ford & - \\
\hline \multirow{5}{*}{$\begin{array}{l}\text { Concentration on } \\
\text { single partners }\end{array}$} & Kia & 0.7194 \\
\hline & Nissan & 0.7194 \\
\hline & Volkswagen & 0.7194 \\
\hline & BYD & 0.7194 \\
\hline & GM & 0.7194 \\
\hline \multirow{2}{*}{ Open partnering } & Toyota & 6.4748 \\
\hline & Hyundai & 1.4388 \\
\hline
\end{tabular}

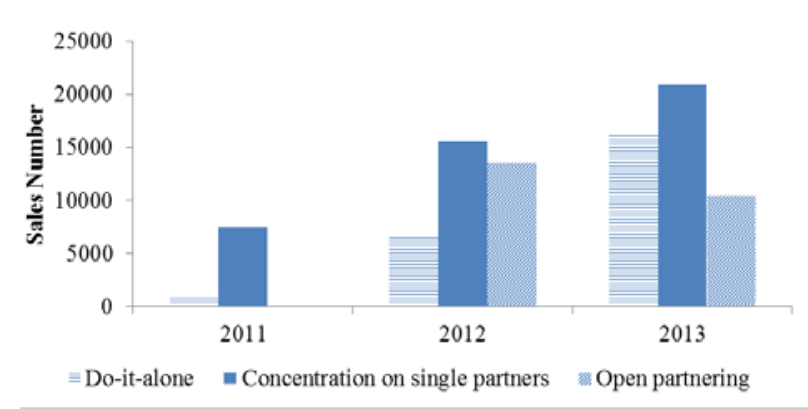

Figure 4. Average sales numbers of the electric vehicles for each strategic cluster (Source: Own figure)

The main concern of the research is whether the differences in partnering behavior have an impact on the firm performance. The study has already successfully identified the differing types of strategic partnering behavior. Because the market for LIB powered electric vehicle is in its infancy, where a sufficient amount of data sets was not available, the average value of sales figure has been taken for each strategic cluster. Since the comparison has been based on the median value of sales figure and thus provides a very abstract picture of performance, the results should be interpreted with caution. At first glance it seems that Do-it-alone and Concentrated partnering behavior are positively linked with the performance, while firm in open partnering approach experienced a minor reduction in sales figures from 2012 to 2013. When only considering the absolute sales figures, firms entering selective partner relationships generate the highest volume of sales. However, when comparing the figures based on the annual growth rate, firms with the doit-alone strategy achieve better outcomes. Thus, an inverted u-shaped relationship between the cooperation intensity and the performance cannot be confirmed based on these findings. One can argue that there is rather a reciprocally proportional correlation among them. However, since an abstract comparison based on insufficient data has been made, no reliable statements can be made whether the differences in strategic behavior 
actually have impact on the economic success or not. Because of the fact that the market is still very immature, it is too early to draw definitive conclusions on the impact of strategic behavior. If the trends continue develop in such a way that the firm with lesser amount of joint patents generates higher sales volume, more strategic partnering in form of licensing can be expected in future.

\section{Conclusion}

Numerous studies have underlined the importance of finding the right balance between the exploration and exploitation (O' Reilly and Tushman, 2004). It is a wellknown factor that companies actively engaged in interorganizational relationships such as strategic alliances or joint ventures expect positive benefits throughout the period of cooperation. This study contributes to the existing literature on the benefits of co-operation on the outcome side in two different ways. First, it was possible to distinguish between three common types of strategic partnering behavior based on the patent level analysis: open-partnering, concentration on single partners and doing it alone. Second, although this study was not successful in proving a direct connection between the cooperation intensity and economic success, there exists a weak signal that a joint ownership of patent does not necessarily contribute to success. Furthermore, this study found evidence for a high co-patenting activity in a growing business environment.

Furthermore, the outcomes of this study can contribute to the corporate decision-making process. In emerging technological areas, firms tend to develop strong R\&D partnerships. Before entering into R\&D cooperation, firms must be aware of the partnering behavior of potential partners. While each partnering approach has its advantages and disadvantages, the choice of strategic partner often depends on the innovativeness and on the type of relationship. If firms are aware of the partnering approach of the potential partnering firm beforehand, they can make the right decisions in the choice of strategic partner for their R\&D activities.

\section{Outlook}

Despite of the findings and insights gained from the analysis, the current study is subject to several limitations. As already mentioned above, relying solely on patentbased relationships to construct measures of cooperation intensity might be misdirecting, since firm engage in cooperation projects without intending to file a patent. A distinction between horizontal and vertical cooperation partners as well as a differentiation between the cooperation type (firms, universities, individuals) has not been made. Under consideration of these aspects, a more detailed picture of cooperating network of suppliers and partners can be obtained. Also it would be interesting to investigate and to compare the patent-based and nonpatent based supplier and manufacturer relationships. Moreover, sales numbers as output variable needs to be questioned. On the one hand, sales numbers were only available for the last few years, which did not allow a proper representation of sales trends. On the other hand, the data does not reveal the economic success, since the sales figure do not report profits. Due to the lack of reliable data (sales volume, EBIT) in a growing business market environment, a simple comparison has been made. The creation of more reliable results might be possible, if the market has matured or if more reliable source of data could be applied.

With regard to these limitations, upcoming researches may be extended by following aspects: First, it would be interesting to find out what the motives behinds the differences in engaging joint ownership of patents are. Second, the proposed research framework should be updated and evaluated with other data (e.g. surveys). Next, the investigation of cooperative behavior in relation to other performance variables as time-to-market, technology adoption, etc. can deliver new insights for a better understanding of the partnering strategy - performance relationship. Finally, it would be interesting to see whether there is a trend of market convergence, whereby the traditional industry boundaries are blurring and companies outside the sector will enter into automotive industry's value chain not only as a supplier but also as a competitor.

\section{Acknowledgement}

We have no competing interest.

\section{References}

[1] Anderson, J. C.; Narus, J. A. (1990): A Model of Distributor Firm and Manufacturer Firm Working Partnerships, in: Journal of Marketing, Vol.54, No. 1, p. 42-58.

[2] Ansoff, H. I. (1965): Checklist for Competitive and Competence Profiles; in Ansoff, H. I. (ed.): Corporate Strategies, New York: McGraw-Hill, p. 89-99.

[3] Barney, Jay (1991): Firm Resources and Sustained Competitive Advantage, in: Journal of Management, Vol. 17, 1, p. 99-120.

[4] Becker, W.; Dietz, J. (2004): R\&D cooperation and innovation activities of firms - evidence for the German manufacturing industry, in: Research Policy, Vol. 33, p. 209-223.

[5] Belderbos, R.; Cassiman, B.; Faems, D.; Leten, B.; Van Looy, B. (2013): Co-ownership of intellectual property: Exploring the value-appropriation and value-creation implications of copatenting with different partners, Paper presented at the $35^{\text {th }}$ DRUID Celebration Conference 2013, Barcelona, Spain, 17-19 June.

[6] Belderbos, R.; Faems, D.; Leten, B.; Van Looy, B. (2010): Technological Activities and Their Impact on the Financial Performance of the Firm: Exploitation and Exploration within and between Firms, in: Journal of Product Innovation Management, Vol. 27, p. 869-882

[7] Bensaou, M. (1997): Interorganizational Cooperation: The Role of IT, in: Information Systems Research, Vol. 8, 2, p. 107-124.

[8] Brown, S.; Pyke, D.; Steenhof, P. (2010): Electric vehicles: the role and importance of standards in an emerging market, in: Energy Policy, Vol.38, p. 3797-3806.

[9] Buckley, P. J.; Casson, M. C. (1988): A theory of cooperation in international business, in: Contractor, F. J.; Lorange, P. (eds.): Cooperative strategies in international business: Joint ventures and technology partnerships between firms, Lexington, MA: Lexington Books, p. 31-54.

[10] Cao, M.; Zhang, Q. (2010): Supply chain collaborative advantage: a firm's perspective, in: International Journal of Production Economics, Vol.128, 1, p. 358-367.

[11] Chesbrough, H. W. (2003): The Era of Open Innovation, in: MIT Sloan Management Review, Vol. 44, 3, p. 35-41.

[12] Cheung, M.; Myers, M. B.; Mentzler, J. T. (2010): Does relationship learning lead to relationship value? A cross-national 
supply chain investigation, in: Journal of Operations Management, Vol.28, p. 472-487.

[13] Chugan, P.K. (1995): R\&D Thrust in Developing Countries - A Case of Indian Automobile Ancillary Industry, in:NMIMS Management Review, Vol.7, No.2, p. 50-67.

[14] Clark, K. B.; Fujimoto, T. (1989): Lead Time in Automobile Product Development - Explaining the Japanese Advantage, in: Journal of Engineering and Technology Management, Vol.6, p. 25-58.

[15] Combs, J. G.; Ketchen Jr., D. J. (1999): Explaining Interfirm Cooperation and Performance: Toward a Reconciliation of Predictions from the Resource-Based View and Organizational Economics, in: Strategic Management Journal, Vol.20, 9, p. 867888.

[16] Curran, S.; Leker, J. (2011): Patent indicators for monitoring convergence - Examples from NFF and ICT, in: Technological Forecasting and Social Change, 78 (2), p. 256-273.

[17] Cusumano, M. A.; Takeishi, A. (1991): Supplier Relations and Management: A Survey of Japanese, Japanese- Transplant, and U.S. Auto Plants, in: Strategic Management Journal, Vol. 12, 8, p. 563-588.

[18] Das, T. K.; Teng, B. S. (1998): Resource and Risk Management in the Strategic Alliance Making Process, in: Journal of Management, Vol. 24, 1, p. 21-42.

[19] Day, G. (1994): The capabilities of market-driven Organizations, in: Journal of Marketing, Vol. 58, 4, p. 37-52.

[20] Devlin, G.; Bleackley, M. (1988): Strategic Alliances Guidelines for success, in: Long Range Planning, Vol. 21, 5, p. 18-23.

[21] Droge, C.; Jayaram, J.; Vickery, S. K. (2004): The effects of internal versus external integration practices on time-based performance and overall firm performance, in: Journal of Operations Management, Vol. 22, p. 557-573.

[22] Dyer, J. H.; Chu, W. (2003): The Role of Trustworthiness in Reducing Transaction Costs and Improving Performance: Empirical Evidence from the United States, Japan, and Korea, in: Organization Science, Vol. 14, 1, p. 57-68.

[23] Dyer, J. H.; Singh, H. (1998): The Relational View: Cooperative Strategy and Sources of Interorganizational Competitive Advantage, in: The Academy of Management Review, Vol. 23, 4, p. 660-679.

[24] Dyer, J. H; Ouchi, W. G. (1993): Japanese style partnerships: Giving companies a competitive edge, in: Sloan Management Review; Vol. 35, 1, p. 51-63.

[25] Dyer, J. H. (1997): Effective interfirm collaboration: How firms minimize transaction costs and maximize transaction value, in: Strategic Management Journal, Vol. 18, p. 535-556.

[26] Eisenhardt, K. M.; Martin, J. A. (2000): Dynamic capabilities: What are they?, in: Strategic Management Journal, Vol. 21, 10-11, p. 1105-1122.

[27] Eisenhardt, K. M.; Schoonhoven, C. B. (1996): Resource-based view of strategic alliance formation: Strategic and social effects of entrepreneurial firms, in:Organizational Science, Vol. 7, p. 136150.

[28] Faems, D.; Van Looy, B.; Debackere, K. (2005): Interorganizational Collaboration and Innovation: Toward a Portfolio Approach, in: Journal of Product Innovation Management, Vol. 22, 3, p. 238-250.

[29] Fliess, S.; Becker, U. (2006): Supplier integration-Controlling of co-development processes, in: Industrial Marketing Management, Vol. 35, p. 28-44.

[30] Flynn, B. B.; Huo, B.; Zhao, X. (2010): The impact of supply chain integration on performance: A contingency and configuration approach, in: Journal of Operations Management, Vol. 28, p. 58-71.

[31] Flynn, P. C. (2002): Commercializing an alternate vehicle fuel: lessons learned from natural gas for vehicles, in: Energy Policy, Vol.30, p.613-619.

[32] Freeman, L. C. (1979): Centrality in Social Networks Conceptual Clarification, in: Social Networks, Vol. 1, p. 215-239.

[33] Gatignon, H.; Robertson, T. S. (1989): Technology diffusion: an empirical test of competitive effects, in: Journal of Marketing, Vol. 53,1, p. 35-49.

[34] Gemünden, H. G.; Ritter, T.; Heydebreck, P. (1996): Network configuration and innovation success: An empirical analysis in German high-tech industries, in:International Journal of Research in Marketing, Vol. 13, 5, p. 449-462.

[35] Giuri, Paola; Mariani, Myriam; Brusoni, Stefano; Crespi, Gustavo; Francoz, Dominique; Gambardella, Alfonso; Garcia-Fontes,
Walter; Geunac, Aldo; Gonzales, Raul; Harhoff, Dietmar; Hoisl, Karin; Le Bas, Christian; Luzzi, Alessandra; Magazzini, Laura; Nesta, Lionel; Nomaler, Önder; Palomeras, Neus; Patel, Pari; Romanelli, Marzia; Verspagen, Bart (2007): Inventors and invention processes in Europe: Results from the PatVal-EU survey, in: Research Policy, Vol. 36, p. 1107-1127.

[36] Grant, R. M.; Baden-Fuller, C. (2004): A Knowledge Accessing Theory of Strategic Alliances, in: Journal of Management Studies, Vol. 41, 1, p. 61-84

[37] Gruner, K. E.; Homburg, C. (2000): Does Customer Interaction Enhance New Product Success?, in: Journal of Business Research, Vol. 49, p. 1-14.

[38] Haeussler, C.; Patzelt, H.; Zahra, S. A. (2010): Strategic alliances and product development in high technology new firms: The moderating effect of technological capabilities, in: Journal of Business Venturing, Vol. 27, 2, p. 217-233.

[39] Hagedoorn, J. (1993): Understanding the rationale of strategic technology partnering: Interorganizational modes of cooperation and sectoral differences, in: Strategic Management Journal, Vol. 14, p. 371-385

[40] Hagedoorn, J. (2002): Inter-firm R\&D partnership: An overview of major trends and patterns since 1960, in: Research Policy, Vol. 31, p. 477-492.

[41] Hagedoorn, J.; Narula, R. (1996): Choosing Organizational Modes of Strategic Technology Partnering: International Sectoral Differences, in: Journal of International Business Studies, Vol. 27, 2, p. $265-284$

[42] Hagedoorn, John (2003): Sharing intellectual property rights - an exploratory analysis of joint patenting among companies, in: Industrial and Corporate Change, Vol. 12, 5, p. 1035-1050.

[43] Handfield, R. B. (1993): A resource dependence perspective of Just-in-Time purchasing, in: Journal of Operations Management, Vol. 11, p. 289-311.

[44] Haythornthwaite, C. (1996): Social Network Analysis: An approach and Technique for the study of Information Exchange, in: Library \& Information Science Research, Vol. 18, p. 323-342.

[45] Hess, A. M.; Rothaermel, F. T. (2011): When are assets complementary? Star scientists, strategic alliances, and innovation in the pharmaceutical industry, in: Strategic Management Journal, Vol. 32, p. 895-909.

[46] Jiang, Z.; Jain, D. C. (2012): A Generalized Norton-Bass Model for Multigeneration Diffusion, in: Management Science, Vol. 58, 10, p. 1887-1897.

[47] Klioutch, I.; Leker, J. (2011): Supplier involvement in customer new product development: New insights from the supplier's perspective, in: International Journal of Innovation Management, Vol. 15, 1, p. 231-248.

[48] Koufteros, X. A.; Vonderembse, M.; Jayaram, J. (2005): Internal and external integration for product development: the contingency effects of uncertainty, equivocality, and platform strategy, in: Decision Sciences, Vol. 36, 1, p. 97-133.

[49] Kuester, S.; Gatignon, H.; Robertson, T. S. (2000): Firm Strategy and Speed of Diffusion, in Mahajan, V.; Muller, E.; Wind, Y. (ed.) New Product Diffusion Models, Boston: Kluwer, p. 27-48.

[50] Li, T.; Calantone, R. J. (1998): The Impact of Market Knowledge Competence on New Product Advantage: Conceptualization and Empirical Examination, in: Journal of Marketing, Vol. 62, 4, p. 13-29.

[51] Maijoor, S., van Witteloostuijn, A. (1996): An empirical test of the re-source-based theory: Strategic regulation in the Dutch audit industry, in: Strategic Management Journal, Vol. 17, 7, p. 549569.

[52] Maloni, M.; Benton, W. C. (2000): Power influence in the supply chain, in: Journal of Business Logistics, Vol. 21, 1, p. 49-73.

[53] Meade, N.; Islam, T. (2006): Modelling and forecasting the diffusion of innovation - A 25-year review, in: InternationalJournal of Forecasting, Vol. 22, p. 519-545.

[54] Morgan, R. M.; Hunt, S. D. (1994): The Commitmment - Trust Theory of Relationship Marketing, in: Journal of Marketing, Vol. 58, 3, p. 20-38.

[55] Mowery, D. C.; Oxley, J. E.; Silverman, B. S. (1998): Technological overlap and interfirm cooperation: implications for the resource-based view of the firm, in: Research Policy, Vol. 27, p. 507-523.

[56] O’Reilly III, C. A.;Tushman, M. L. (2008): Ambidexterity as a dynamic capability: Resolving the innovator's dilemma. Research in Organizational Behavior 28 (2008) 185-206. 
[57] Parkhe, A. (1993): Strategic Alliance Structuring: A Game Theoretic and Transaction Cost Examination of Interfirm Cooperation, in: The Academy of Management Journal, Vol. 36, 4, p. 794-829.

[58] Perks, H.; Jeffery, R. (2006): Global network configuration for innovation: a study of international fiber innovation, in: $R \& D$ Management Journal, Vol. 36, 1, p. 67-83.

[59] Powell, T. C. (1992): Strategic planning as competitive advantage, in: Strategic Management Journal, Vol. 13, p. 551-558.

[60] Rogers, E. M. (2003): Diffusion of Innovations, 5. Edition, New York et al.: Free Press.

[61] Rothaermel, F. T. (2001): Complementary assets, strategic alliances, and the incumbent's advantage: an empirical study of industry and firm effects in the biopharmaceutical industry, in: Research Policy, Vol. 30, p. 1235-1251.

[62] Schumpeter, J. (1934): The Theory of Economic Development, Cambridge, MA: Harvard University Press.

[63] Song, W.; Ming, X.; Xu, Z. (2013): Risk evaluation of customer integration in new product development under uncertainty, in: Computers \& Industrial Engineering, Vol. 65, p. 402-412.

[64] Stoneman, P. (1983): The Economic Analysis of Technological Change, New York: Oxford University Press.
[65] Teece, D. J.; Pisano, G.; Shuen, A. (1997): Dynamic capabilities and strategic management, in: Strategic Management Journal, Vol. 18, 7, p. 509-533.

[66] Veugelers, R.; Cassiman, Bruno. (2005): R\&D cooperation between firms and universities. Some empirical evidence from Belgian manufacturing, in: International Journal of Industrial Organization, Vol. 23, p. 355-379.

[67] Vickery, S. K.; Jayaram, J.; Droge, C.; Calantone, R. (2003): The effects of an integrative supply chain strategy on customer service and financial performance: an analysis of direct versus indirect relationships, in: Journal of Operations Management, Vol. 21, p. 523-539.

[68] Wagner, R., Preschitschek, N., Passerini, S., Leker, J., Winter, M. (2013): Current research trends and prospects among the various materials and designs used in lithium-based batteries, in: Journal of Applied Electrochemistry, Vol. 43, p. 481-496.

[69] Wernerfelt, B. (1984): A Resource-based View of the Firm, in: Strategic Management Journal, Vol. 5, 2, p. 171-180.

[70] Whipple, J. M.; Frankel, R. (2000): Strategic Alliance Success Factors, in: Journal of Supply Chain Management, Vol. 36, 2, p. 21-28.

[71] Yang, L.; Xu, J.; Neuhäusler, P. (2013): Electric vehicle technology in China: An exploratory patent analysis, in: World Patent Information, Vol. 35, p. 305-312. 